\title{
Transfer of Halomonas canadensis and Halomonas israelensis to the genus Chromohalobacter as Chromohalobacter canadensis comb. nov. and Chromohalobacter israelensis comb. nov.
}

\footnotetext{
1 Departamento de Microbiología y Parasitología, Facultad de Farmacia, Universidad de Sevilla, 41012 Seville, Spain

2 Lehrstuhl für Mikrobiologie, Technische Universität München, 85350 Freising, Germany
}

\author{
David R. Arahal, ${ }^{1,2}$ M. Teresa García, ${ }^{1}$ Wolfgang Ludwig, ${ }^{2}$ \\ Karl H. Schleifer ${ }^{2}$ and Antonio Ventosa ${ }^{1}$

\begin{abstract}
Author for correspondence: Antonio Ventosa. Tel: +34 95 4556765. Fax: + 34954628162.
\end{abstract} \\ e-mail:ventosa@cica.es
}

\begin{abstract}
$16 S$ rRNA gene sequence comparisons and DNA-DNA hybridization data support the conclusion that two species previously described as members of the genus Halomonas, Halomonas israelensis and Halomonas canadensis, should be placed in the genus Chromohalobacter. Both $H$. israelensis ATCC 43985' $\left(=\mathrm{Ba}_{1}{ }^{\top}\right.$ ) and $H$. canadensis ATCC 43984' ( = NRCC 41227') have been used extensively for physiological studies for many years; nevertheless, they were not named and classified taxonomically until quite recently. Their phenotypic resemblance (at least $65 \%$ Jaccard similarity) to some members of the genus Halomonas and the degree of DNA-DNA relatedness (lower than $60 \%$ ) to other described species of this genus permitted the conclusion that they were distinct species belonging to the genus Halomonas. In this study, the 16S rDNA of both species has been sequenced completely and found to share higher similarity to the available sequences of the moderately halophilic bacterium Chromohalobacter marismortui than to sequences of members of the genus Halomonas. C. marismortui is the sole species of the genus Chromohalobacter, also included in the family Halomonadaceae, and shares many phenotypic features with $H$. canadensis and $H$. israelensis. It is proposed that the two species should be renamed as Chromohalobacter canadensis comb. nov. and Chromohalobacter israelensis comb. nov. An emended description of the genus Chromohalobacter is given in order to include the features of these two species.
\end{abstract}

Keywords: Halomonas, Chromohalobacter canadensis, Chromohalobacter israelensis, moderately halophilic bacteria, $16 \mathrm{~S}$ rRNA sequence

\section{INTRODUCTION}

Strain $\mathrm{Ba}_{1}^{\mathrm{T}}\left(=\right.$ ATCC $\left.43985^{\mathrm{T}}\right)$ was isolated from the Dead Sea by Rafaeli-Eshkol (1968) and was the subject of several physiological and biochemical studies dealing mainly with the effects of $\mathrm{NaCl}$ on respiratory enzymes, osmoregulatory mechanisms and ion transporters (Ken-Dror \& Avi-Dor, 1985; Ken-Dror et al.,

The EMBL accession numbers for the $16 \mathrm{~S}$ rRNA gene sequences of Halomonas canadensis ATCC $43984^{\top}$, Halomonas israelensis ATCC $43985^{\top}$ and Halomonas salina F8-11 ${ }^{\top}$ are AJ295143, AJ295144 and AJ295145, respectively.
1984; Rafaeli-Eshkol, 1968). Strain NRCC $41227^{\mathrm{T}}$ was reported as a medium contaminant by Matheson et al. (1976) and served as a model for some physiological studies (Falkenberg et al., 1976; Ken-Dror et al., 1984). A summary of these studies conducted on the two strains can be found in a recent review (Ventosa et al., 1998) about moderately halophilic bacteria, which are defined as those micro-organisms able to grow optimally in media containing $3-15 \%(\mathrm{w} / \mathrm{v})$ $\mathrm{NaCl}$ (Kushner \& Kamekura, 1988). During all this time, they were referred to simply as strains $\mathrm{Ba}_{1}$ and NRCC 41227. It was not until 27 and 19 years, respectively, after the reports of their isolation that 
they were classified as members of the genus Halomonas and named Halomonas israelensis and Halomonas canadensis (Huval et al., 1995). The taxonomic study of Huval et al. (1995) was done by comparing these two strains with four other Halomonas strains and taking 125 phenotypic features into account. A further comparison, using a larger number of related reference strains, or a phylogenetic study has never been done, to our knowledge, and this led us to carry out a detailed study of these two Halomonas species.

\section{METHODS}

Strains and culture conditions. H. israelensis ATCC $43985^{\mathrm{T}}$, H. canadensis ATCC $43984^{\mathrm{T}}$, Halomonas salina $\mathrm{F} 8-11^{\mathrm{T}}$, Halomonas elongata ATCC $33173^{\mathrm{T}}$, H. elongata DSM 3043 , Halomonas halodurans ATCC $29686^{\mathrm{T}}$, Chromohalobacter marismortui ATCC $17056^{\mathrm{T}}$ and C. marismortui A-492 were grown on SW-10 medium (Nieto et al., 1989), which contained a final salt concentration of about $10 \%(\mathrm{w} / \mathrm{v})$ and $0.5 \%(\mathrm{w} / \mathrm{v})$ yeast extract (Difco). The $\mathrm{pH}$ was always adjusted to $7 \cdot 2$. Cultures were incubated at $37^{\circ} \mathrm{C}$ in an orbital shaker (New Brunswick Scientific) at 200 strokes $\mathrm{min}^{-1}$. Fresh mounts from exponentially growing cultures of $H$. canadensis and $H$. israelensis were examined by light microscopy (phase-contrast) to determine their cell size. Hydrolysis of casein, aesculin, gelatin, DNA and starch, as well as other biochemical and nutritional tests, were performed as reported previously (Ventosa et al., 1982).

Extraction of genomic DNA and determination of DNA base composition. DNA was extracted and purified by the method of Marmur (1961). Purity was assessed from the $A_{260} / A_{280}$ and $A_{230} / A_{260}$ ratios (Johnson, 1994). The $\mathrm{G}+\mathrm{C}$ content of the DNA was determined from the mid-point value $\left(T_{\mathrm{m}}\right)$ of the thermal denaturation profile (Marmur \& Doty, 1962) obtained with a Perkin-Elmer UV-Vis $551 \mathrm{~S}$ spectrophotometer at $260 \mathrm{~nm}$; this instrument was programmed for temperature increases of $1{ }^{\circ} \mathrm{C} \mathrm{min}^{-1}$. The $T_{\mathrm{m}}$ was determined by a graphical method described by Ferragut \& Leclerc (1976) and the $G+C$ content was calculated from this temperature by using the equation of Owen \& Hill (1979), in $0.1 \times$ SSC buffer $(0.15 \mathrm{M} \mathrm{NaCl}$ buffered with $0.015 \mathrm{M}$ trisodium citrate, $\mathrm{pH} 7 \cdot 0$ ). The $T_{\mathrm{m}}$ value of reference DNA from Escherichia coli NCTC 9001 was taken as $74.6{ }^{\circ} \mathrm{C}$ in $0 \cdot 1 \times$ SSC (Owen \& Pitcher, 1985).

Preparation of labelled DNA and DNA-DNA hybridization experiments. DNA was labelled by the multiprime system with a commercial kit (RPN 1601Y; Amersham) that

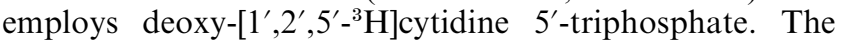
mean specific activity obtained with this procedure was $8.4 \times 10^{6}$ c.p.m. $\mu \mathrm{g}^{-1}$ DNA. The labelled DNA was denatured before hybridization by heating at $100{ }^{\circ} \mathrm{C}$ for 5 min and then placed on ice.

DNA-DNA hybridization studies were performed by the competition procedure of the membrane method described by Johnson (1994). Competitor DNAs were sonicated (Braun Melsungen) at $50 \mathrm{~W}$ for two periods of $15 \mathrm{~s}$. Membrane filters (HAHY; Millipore), $0.5 \mathrm{~cm}$ in diameter, containing reference DNA $\left(25 \mu \mathrm{g} \mathrm{cm}^{-2}\right)$ were placed in $5 \mathrm{ml}$ screw-capped vials (Greiner) that contained the labelled, sheared, denatured DNA and the denatured, sheared competitor DNA. The ratio of the concentrations of competitor to labelled DNA was at least 150:1. The final volume and concentration were adjusted to $140 \mu \mathrm{l}, 2 \times \mathrm{SSC}$ and $30 \%$ formamide. The optimal hybridization temperatures were $56.9{ }^{\circ} \mathrm{C}$ for $H$. canadensis and $58.2^{\circ} \mathrm{C}$ for $H$. israelensis, which are within the limits of validity for the filter method (De Ley \& Tijtgat, 1970). The vials were shaken gently for $18 \mathrm{~h}$ in a water bath (Grant Instruments); these procedures were done in triplicate. After hybridization, the filters were washed in $2 \times \mathrm{SSC}$ at the optimal renaturation temperatures reported above. The radioactivity bound to the filters was measured in a liquid scintillation counter (Beckman Instruments) and the percentage similarity was calculated according to Johnson (1994). At least two independent determinations were carried out for each experiment and the reported results are the mean values.

Phylogenetic analysis. Isolation of genomic DNA from $H$. israelensis ATCC $43985^{\mathrm{T}}, H$. canadensis ATCC $43984^{\mathrm{T}}$ and $H$. salina $\mathrm{F} 8-11^{\mathrm{T}}$, in vitro amplification of the $16 \mathrm{~S}$ rRNA genes and direct sequencing of the PCR-amplified 16S rDNA fragments were carried out by using methods that have been described previously (Springer et al., 1993).

Data analyses, including more than 20000 complete or almost complete 16S rRNA sequences (at least 1400 bases) available from rRNA sequence databases, were performed by using the ARB software package (Ludwig \& Strunk, 1996). The most closely related sequences were used, together with a large number of outgroup sequences, to construct a similarity matrix. A tree was derived from the corrected distance values by using the neighbour-joining method (Saitou \& Nei, 1987). Maximum-parsimony- and maximumlikelihood-based trees, respectively using the full dataset or a selection of about 50 sequences, were obtained and compared in order to make an estimate of the confidence. The effects on the results of a base-frequency filter in the sequence comparison analysis were also evaluated.

\section{RESULTS AND DISCUSSION}

We determined the cell size of $H$. canadensis and $H$. israelensis and some biochemical features that were not reported in the descriptions of these two species or in subsequent publications. Both strains were negative for the hydrolysis of casein, gelatin, DNA, aesculin and starch. The $\mathrm{G}+\mathrm{C}$ contents of the DNA of these two strains were also estimated by the thermal denaturation method (Table 1). Our values, 62 and $65 \mathrm{~mol} \%$ for $H$. canadensis and $H$. israelensis, differ slightly from the previously published values (57 and $64 \mathrm{~mol} \%$, respectively), probably due to the fact that a different method (buoyancy) was used. Several tests allowed the differentiation of $H$. canadensis and $H$. israelensis from each other as well as from $C$. marismortui (Table 2) or species of the genus Halomonas. In the original proposal (Huval et al., 1995), H. canadensis and H. israelensis were classified within the genus Halomonas according to their phenotypic characteristics and DNA-DNA hybridization experiments, but only four Halomonas strains (representing three species) were used for comparison. However, the phylogenetic relationships of these two species were not determined. In this study, the almost complete 16S rDNA sequences (ca. 1530 bases) of $H$. canadensis and $H$. israelensis were obtained and their phylogenetic position was determined. We found that 
Table 1. DNA G $+\mathrm{C}$ contents and levels of DNA-DNA relatedness for $H$. canadensis, $H$. israelensis and some related reference strains of the genera Halomonas and Chromohalobacter

\begin{tabular}{|c|c|c|c|}
\hline \multirow[t]{2}{*}{ Source of unlabelled DNA } & \multirow[t]{2}{*}{$\mathrm{G}+\mathrm{C}$ content $(\mathrm{mol} \%)^{*}$} & \multicolumn{2}{|c|}{ Similarity (\%) to ${ }^{3} \mathrm{H}$-labelled DNA from: } \\
\hline & & H. canadensis ATCC 43984 $^{\mathrm{T}}$ & H. israelensis ATCC $43985^{\mathrm{T}}$ \\
\hline H. canadensis ATCC $43984^{\mathrm{T}}$ & $62 \cdot 0$ & 100 & 36 \\
\hline H. israelensis ATCC $43985^{\mathrm{T}}$ & $65 \cdot 0$ & 40 & 100 \\
\hline C. marismortui ATCC $17056^{\mathrm{T}}$ & $62 \cdot 3^{a}$ & 39 & 37 \\
\hline C. marismortui A-492 & $63 \cdot 9^{a}$ & 25 & 40 \\
\hline H. elongata ATCC $33173^{\mathrm{T}}$ & $60 \cdot 5^{b}$ & 0 & 0 \\
\hline H. elongata DSM 3043 & $64 \cdot 2$ & 35 & 50 \\
\hline H. halodurans ATCC $29686^{\mathrm{T}}$ & $63 \cdot 2^{c}$ & 0 & 0 \\
\hline
\end{tabular}

* Data were taken from this study and from Ventosa et al. (1989) (a), Vreeland et al. (1980) (b) and Hebert \& Vreeland (1987) (c).

Table 2. Phenotypic characteristics that differentiate C. marismortui, H. canadensis and $H$. israelensis

Data were taken from Huval et al. (1995), Ventosa et al. (1989) and this study. Characters are scored as: +, positive; -, negative.

\begin{tabular}{|c|c|c|c|}
\hline Characteristic & C. marismortui ATCC $17056^{\mathrm{T}}$ & H. canadensis ATCC $\mathbf{4 3 9 8 4}^{\mathrm{T}}$ & H. israelensis ATCC $43985^{\mathrm{T}}$ \\
\hline Cell size $(\mu \mathrm{m})$ & $0 \cdot 6-1 \cdot 0 \times 1 \cdot 5-4 \cdot 0$ & $0 \cdot 6-1 \cdot 2 \times 2 \cdot 0-3 \cdot 8$ & $0 \cdot 6-0.9 \times 1 \cdot 5-4 \cdot 2$ \\
\hline Pigmentation & Brown-yellow & White & Cream \\
\hline \multicolumn{4}{|c|}{$\begin{array}{l}\mathrm{NaCl} \text { concentration for growth } \\
(\% \mathrm{w} / \mathrm{v})\end{array}$} \\
\hline Range & $1 \cdot 0-30$ & $3-25$ & $3 \cdot 5-20$ \\
\hline Optimum & 10 & 8 & 8 \\
\hline Temperature range $\left({ }^{\circ} \mathrm{C}\right)$ & $5-45$ & $15-45$ & $15-45$ \\
\hline $\mathrm{pH}$ range & $5-10$ & $5-9$ & $5-9$ \\
\hline Indole production & - & + & + \\
\hline Nitrate reduction & - & + & + \\
\hline Phosphatase & - & + & - \\
\hline Simmons citrate & + & - & - \\
\hline Lysine decarboxylase & - & + & + \\
\hline Ornithine decarboxylase & - & + & + \\
\hline \multicolumn{4}{|l|}{ Acid production from: } \\
\hline Maltose & + & - & + \\
\hline Sucrose & + & - & + \\
\hline Trehalose & + & - & - \\
\hline \multicolumn{4}{|l|}{ Growth on: } \\
\hline Cellobiose & - & + & + \\
\hline Aesculin & - & + & + \\
\hline Starch & + & - & + \\
\hline
\end{tabular}

they share $97 \cdot 1 \%$ overall similarity. The similarities between either of them and the available sequences of members of the genus Halomonas were significantly lower, ranging from 92.8 to $95.2 \%$. In contrast, when compared with the sequences (U78719, X87219, X87220, X87221 and X87222) from five strains of $C$. marismortui (T1093, ATCC $17056^{\mathrm{T}}$, A-62, A-100 and A-492, respectively), higher overall similarity was found: $H$. canadensis and $H$. israelensis respectively showed 98.2 and $96.8 \% 16 \mathrm{~S}$ rRNA similarity to the sequence of the type strain of C. marismortui.
In a preliminary phylogenetic tree (not shown) derived from the matrix distances, the new sequences from $H$. canadensis and $H$. israelensis did indeed group with the five sequences of $C$. marismortui, forming a cluster separated from the other species of the genus Halomonas with the exception only of Halomonas marina, which represents the deepest branching of the group. The $16 \mathrm{~S}$ rRNA sequence of $H$. salina $\mathrm{F} 8-11^{\mathrm{T}}$ (AJ295145) determined in this study is almost identical to the sequences L42617 (from $H$. salina ATCC $49509^{\mathrm{T}}$ ), AJ243447 (from H. salina ATCC $49509^{\mathrm{T}}$ ) and 


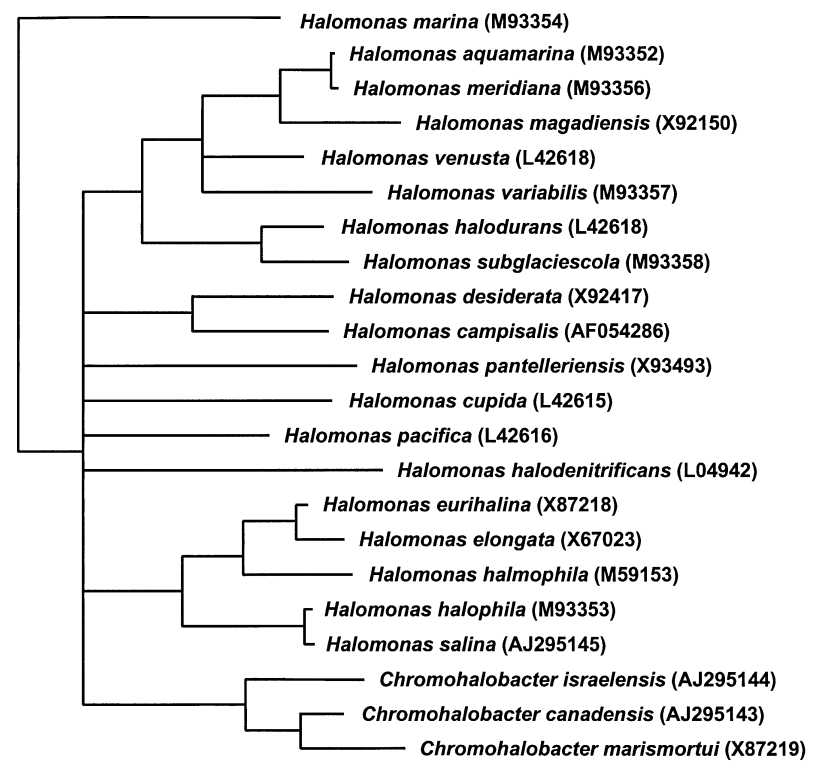

Fig. 1. Phylogenetic tree derived from analysis of the $16 \mathrm{~S}$ rRNA sequences of C. israelensis, C. canadensis, C. marismortui and the type strains of species of the genus Halomonas (accession numbers in parentheses). Collapsed branches correspond to those whose topology was affected by the method applied. Bar, $5 \%$ sequence difference. The outgroup (not shown) consisted of a collection of more than 100 full sequences.

AJ243448 (from H. salina DSM 5928 ${ }^{\mathrm{T}}$ ). In contrast, sequence X87217, although it apparently has the same origin (H. salina ATCC $49509^{\mathrm{T}}$ ), shares only approximately $96.3 \%$ similarity with any of the above sequences and could therefore represent a mislabelled sequence.

Regardless of the method applied or the set of sequences employed, $H$. canadensis and $H$. israelensis always clustered together with $C$. marismortui, as shown in the phylogenetic tree in Fig. 1. For its reconstruction, possible changes in the topology were evaluated, comparing the results from the three most accepted treeing methods: pairwise distances, maximum-parsimony and maximum-likelihood. Additionally, a filter, in which variable positions (less than $50 \%$ conservation in the sequences of the group that are the subject of this study) were removed, was used to test whether the more conservative part of the dataset yielded results similar to those for the complete dataset. Following the recommendations of Ludwig et al. (1998), the branches that were found to vary in relative order within a cluster depending on the method applied are indicated as multifurcations.

Although the genus Halomonas is not monophyletic and may undergo taxonomic changes in the future, the branch in which $C$. marismortui and the species $H$. canadensis and $H$. israelensis clustered was very stable across the different phylogenetic models that were applied, which can be taken as a strong evidence of the robustness of the topology presented in Fig. 1.

Recent comparative studies on $23 \mathrm{~S}$ rRNA sequences (D. R. Arahal, W. Ludwig, K. H. Schleifer and A. Ventosa, unpublished data) carried out on species of the genera Halomonas and Chromohalobacter confirm this result and clearly support the placement of $H$. canadensis and $H$. israelensis in the genus Chromohalobacter. The close phylogenetic relationship with $C$. marismortui could imply that they might be members of this species and we therefore conducted DNA-DNA hybridization experiments in order to clarify whether they represent different genospecies. Table 1 shows the results obtained from the DNA hybridization experiments. Low values of DNA-DNA relatedness $(40 \%$ or less) were obtained between $H$. canadensis and $H$. israelensis and between both of them and the two $C$. marismortui strains used (the type strain and a reference strain). These data indicate clearly that they represent different species of the genus Chromohalobacter. It is noteworthy that they have high DNA relatedness to strain DSM 3043, a strain deposited as Halomonas elongata but which could be related more closely to the genus Chromohalobacter than to Halomonas. Its taxonomic placement is reconsidered in another study (Arahal et al., 2001).

In summary, all of the different phylogenetic analyses performed are in good agreement and support the inclusion of $H$. canadensis and $H$. israelensis in the genus Chromohalobacter. Furthermore, other data presented in this article are consistent with this reclassification. Therefore, we propose the transfer of $H$. canadensis and $H$. israelensis to the genus Chromohalobacter as Chromohalobacter canadensis comb. nov. and Chromohalobacter israelensis comb. nov. Additionally, a redefinition of the genus Chromohalobacter, which previously comprised only a single species, is included.

\section{Emended description of the genus Chromohalobacter (Ventosa et al. 1989) Arahal et al.}

Cells are Gram-negative, straight or sometimes slightly curved, motile rods that are $0.6-1.2 \times 1.5-4.2 \mu \mathrm{m}$ and occur singly, in pairs and in short chains. Non-sporeforming. Colonies are pigmented cream to brownyellow. Moderate halophiles. Salt is required for 
growth. Optimal growth occurs in the presence of $8-10 \%(\mathrm{w} / \mathrm{v})$ salt. May grow at salt concentrations up to $30 \%(\mathrm{w} / \mathrm{v})$. The broader ranges of temperature and $\mathrm{pH}$ observed for growth are $5-45^{\circ} \mathrm{C}$ and $\mathrm{pH} 5 \cdot 0-10 \cdot 0$. Chemo-organotrophs. Aerobic. Catalase-positive. Most strains reduce nitrate, but $\mathrm{H}_{2} \mathrm{~S}$ is not produced. Negative for urease and phenylalanine deaminase. Casein, DNA, aesculin, gelatin, starch and Tween 80 are not hydrolysed. Acid is produced from arabinose, glucose, glycerol, lactose and xylose. Habitat: the Dead Sea and marine salterns. The DNA base composition ranges from 62 to $65 \mathrm{~mol} \%$, as determined by the thermal denaturation method. The type species is Chromohalobacter marismortui.

\section{Description of Chromohalobacter canadensis (Huval et al. 1995) Arahal et al. comb. nov.}

The description of Chromohalobacter canadensis comb. nov. is identical to that published for $H$. canadensis (Huval et al., 1995) with the addition that the cell size was determined to be $0 \cdot 6-1 \cdot 2 \times 2 \cdot 0-3 \cdot 8 \mu \mathrm{m}$, it is not able to hydrolyse casein, DNA, aesculin, gelatin or starch and the $\mathrm{G}+\mathrm{C}$ content of the DNA is $62 \mathrm{~mol} \%$ ( $T_{\mathrm{m}}$ method). The accession number of the $16 \mathrm{~S}$ rDNA sequence is AJ295143.

The description is based on a single strain, the type strain NRCC $41227^{\mathrm{T}}\left(=\right.$ ATCC $43984^{\mathrm{T}}=\mathrm{DSM} 6769^{\mathrm{T}}$ $=\mathrm{CECT} \quad 5385^{\mathrm{T}}=\mathrm{CCM} \quad 4919^{\mathrm{T}}=\mathrm{CIP} \quad 105571^{\mathrm{T}}=$ NCIMB $13767^{\mathrm{T}}$ ).

\section{Description of Chromohalobacter israelensis (Huval et al. 1995) Arahal et al. comb. nov.}

The description of Chromohalobacter israelensis comb. nov. is the same as that published for $H$. israelensis (Huval et al., 1995) with a few additions: the cell size was determined to be $0 \cdot 6-0.9 \times 1.5-4.2 \mu \mathrm{m}$, hydrolysis of casein, DNA, aesculin, gelatin and starch is negative and the $\mathrm{G}+\mathrm{C}$ content of the DNA is $65 \mathrm{~mol} \%\left(T_{\mathrm{m}}\right.$ method). The accession number of the $16 \mathrm{~S} \mathrm{rDNA}$ sequence is AJ295144.

The description is based on a single strain, the type strain ATCC $43985^{\mathrm{T}}\left(=\mathrm{DSM} 6768^{\mathrm{T}}=\right.$ CECT $5287^{\mathrm{T}}$ $\left.=\operatorname{CCM} 4920^{\mathrm{T}}=\operatorname{CIP} 106853^{\mathrm{T}}=\operatorname{NCIMB} 13766^{\mathrm{T}}\right)$.

\section{ACKNOWLEDGEMENTS}

D. R. A. was the recipient of a fellowship from the Ministerio de Educación y Cultura, Spain. This investigation was supported by grants from the Ministerio de Educación y Cultura, Spain (grants 1FD97-1162 and PB98-1150) and from the Junta de Andalucía.

\section{REFERENCES}

Arahal, D. R., García, M. T., Vargas, C., Cánovas, D., Nieto, J. J. \& Ventosa, A. (2001). Chromohalobacter salexigens sp. nov., a moderately halophilic species that includes Halomonas elongata
DSM 3043 and ATCC 33174. Int J Syst Evol Microbiol 51, $1457-1462$.

De Ley, J. \& Tijtgat, R. (1970). Evaluation of membrane filter methods for DNA-DNA hybridization. Antonie Leeuwenhoek 36, 461-474.

Falkenberg, P., Matheson, A. T. \& Rollin, C. F. (1976). The properties of ribosomal proteins from a moderate halophile. Biochim Biophys Acta 434, 474-482.

Ferragut, C. \& Leclerc, H. (1976). Étude comparative des méthodes de détermination du Tm de l'ADN bactérien. Ann Microbiol 127A, 223-235.

Hebert, A. M. \& Vreeland, R. H. (1987). Phenotypic comparison of halotolerant bacteria: Halomonas halodurans sp. nov., nom. rev., comb. nov. Int J Syst Bacteriol 37, 347-350.

Huval, J. H., Latta, R., Wallace, R., Kushner, D. J. \& Vreeland, R. H. (1995). Description of two new species of Halomonas: Halomonas israelensis sp. nov. and Halomonas canadensis sp. nov. Can J Microbiol 41, 1124-1131.

Johnson, J. L. (1994). Similarity analysis of DNAs. In Methods for General and Molecular Bacteriology, pp. 655-682. Edited by P. Gerhardt, R. G. E. Murray, W. A. Wood \& N. R. Krieg. Washington, DC: American Society for Microbiology.

Ken-Dror, S. \& Avi-Dor, Y. (1985). Regulation of respiration by $\mathrm{Na}^{+}$and $\mathrm{K}^{+}$in the halotolerant bacterium, $\mathrm{Ba}_{1}$. Arch Biochem Biophys 243, 238-245.

Ken-Dror, S., Shnaiderman, R. \& Avi-Dor, Y. (1984). Uncoupler stimulated $\mathrm{Na}^{+}$pump and its possible role in the halotolerant bacterium, $\mathrm{Ba}_{1}$. Arch Biochem Biophys 229, 640-649.

Kushner, D. J. \& Kamekura, M. (1988). Physiology of halophilic eubacteria. In Halophilic Bacteria, vol. 1, pp. 109-140. Edited by F. Rodriguez-Valera. Boca Raton, FL: CRC Press.

Ludwig, W. \& Strunk, O. (1996). ARB - a software environment for sequence data. http://www.mikro.biologie.tu-muenchen. $\mathrm{de} / \mathrm{pub} / \mathrm{ARB} /$ documentation/arb.ps

Ludwig, W., Strunk, O., Klugbauer, S., Klugbauer, N., Weizenegger, M., Neumaier, J., Bachleitner, M. \& Schleifer, K. H. (1998). Bacterial phylogeny based on comparative sequence analysis. Electrophoresis 19, 554-568.

Marmur, J. (1961). A procedure for the isolation of deoxyribonucleic acid from microorganisms. $J$ Mol Biol 3, 208-218.

Marmur, J. \& Doty, P. (1962). Determination of the base composition of deoxyribonucleic acid from its thermal denaturation temperature. $J$ Mol Biol 5, 109-118.

Matheson, A. T., Sprott, G. D., McDonald, I. J. \& Tessier, H. (1976). Some properties of an unidentified halophile: growth characteristics, internal salt concentration and morphology. Can $J$ Microbiol 22, 780-786.

Nieto, J. J., Fernández-Castillo, R., Márquez, M. C., Ventosa, A., Quesada, E. \& Ruiz-Berraquero, F. (1989). Survey of metal tolerance in moderately halophilic eubacteria. Appl Environ Microbiol 55, 2385-2390.

Owen, R. J. \& Hill, L. R. (1979). The estimation of base compositions, base pairing and genome sizes of bacterial deoxyribonucleic acids. In Identification Methods for Microbiologists, 2nd edn, pp. 217-296. Edited by F. A. Skinner \& D. W. Lovelock. London: Academic Press.

Owen, R. J. \& Pitcher, D. (1985). Current methods for estimating DNA base composition and levels of DNA-DNA hybridization. In Chemical Methods in Bacterial Systematics, pp. 67-93. Edited by M. Goodfellow \& E. Minnikin. London: Academic Press. 
Rafaeli-Eshkol, D. (1968). Studies on halotolerance in a moderately halophilic bacterium. Effect of growth conditions on salt resistance of the respiratory system. Biochem $J$ 109, 679-685.

Saitou, N. \& Nei, M. (1987). The neighbor-joining method: a new method for reconstructing phylogenetic trees. Mol Biol Evol 4, 406-425.

Springer, N., Ludwig, W., Amann, R., Schmidt, H. J., Görtz, H. D. \& Schleifer, K.-H. (1993). Occurrence of fragmented 16S rRNA in an obligate bacterial endosymbiont of Paramecium caudatum. Proc Natl Acad Sci U S A 90, 9892-9895.

Ventosa, A., Quesada, E., Rodríguez-Valera, F., Ruiz-Berraquero, F. \& Ramos-Cormenzana, A. (1982). Numerical taxonomy of moderately halophilic Gram-negative rods. J Gen Microbiol 128, 1959-1968.

Ventosa, A., Gutiérrez, M. C., García, M. T. \& Ruiz-Berraquero, F. (1989). Classification of "Chromobacterium marismortui" in a new genus, Chromohalobacter gen. nov., as Chromohalobacter marismortui comb. nov., nom. rev. Int J Syst Bacteriol 39, 382-386.

Ventosa, A., Nieto, J. J. \& Oren, A. (1998). Biology of moderately halophilic aerobic bacteria. Microbiol Mol Biol Rev 62, 504-544.

Vreeland, R. H., Litchfield, C. D., Martin, E. L. \& Elliot, E. (1980). Halomonas elongata, a new genus and species of extremely salttolerant bacteria. Int J Syst Bacteriol 30, 485-495. 